\title{
ADVERTISING DIGITALIZATION WITHIN SALES NETWORK
}

\author{
Aldankova H. \\ Candidate of sciences (Ph.D.), Senior Lecturer \\ Kostenko S. \\ student \\ Department of Journalism and Advertising \\ Kyiv National University of Trade and Economics, Ukraine
}

Keywords: mobile blindness, generation of thumb, social first creative.

The digital economy as a phenomenon focuses not only on the digitalization of objects itself but also on the environment among numerous objects. This fact raises a plethora of debatable questions related to the availability of relevant digital platforms, investments for their creation, importance of incentives and motivation to use them. Nowadays, digitalization has been the main trend. In the world of modern information technology, time flies faster. Moore's investigation emphasizes that the speed and development of technology keep the tendency to double annually [1]. According to the study by the Center for Digital Transformation of the IMD Business School, within the next five years, $40 \%$ of leading companies will lose their position unless they undergo a digital transformation [2].

The relevance of traditional marketing communication tools for sales networks is steadily declining. The Internet continues to expand dramatically which means that the future is going to be focused on virtual and augmented reality, the development of cyber spot, and mobile advertising. One more profound shift of modern society is the growth of time consumed with smartphones. In 2015, 25\% of the world's population use smartphones. In 2018 this figure increased up to $33 \%$. Consumer priorities have changed. «Mobile blindness» is a term that characterizes the behavior of a modern person. «Ouya yubi sedai» or «generation of a thumb» - the way Japanese people describe the phenomenon [3].

People do not imagine their lives without a smartphone carrying around all the time and complete a lot of tasks with its assistance. This not only saves precious time but also does not bind the reader to a specific place and media platform. Communication methods include short messaging service (SMS), multimedia messaging service (MMS), mobile Internet via WAP, WAP Push services and high-quality multimedia services over $3 \mathrm{G}, 4 \mathrm{G}$ networks. Business cases demonstrate the fact that the use of mobile technologies by 
sales networks accompanied by other forms of sales promotion significantly increase the level of sales. Mobile communication channels have a number of advantages over traditional means of advertising, for example, the response rate in most cases exceeds $10 \%$. Moreover, this is the cheapest form of communication with users. In order to run a trial campaign, a minimum help of third-party companies will be required.

Due to the widespread use of smartphones, the average level of consumers' attention has decreased from 12 seconds in 2008 to 8 seconds in 2015. For example, consumers waiting at store check-outs are more likely to look at a phone rather than on a shelf with products. Being in the queue means the battle for buyers' attention: the impulse versus the habit, chocolate bars Mars against Candy Crush [4]. Some businesses started having advertising on sidewalks in order to catch the attention of smartphone users while walking. Now the fight over the people's attention is between businesses and distractive smartphones [5].

The matter of multichannel promotion of goods and services appeared after the implementation of OMNI-Channel by business - an integrated approach to the buyer, who is able to choose the most convenient sale platform. During the crisis, many businesses have reduced not the number of advertising orders, but the budget dedicated to promotion and media channels. In addition, the development of new technologies reduces the efficiency of traditional advertising communications. As a result, this requires adaptation or development of new approaches of business strategies.

The growing popularity of mobile communication usage has caused that television and print media, increase their content in Digital to be available on any media. People continue reading online on their devices. Access to social networks through mobile devices provides contract important channel to brand communication channel with the target audience [6].

Outdoor advertising will also gradually shift into digital formats. Its functions are the attraction of customers' attention and quickly push them to the purchase. The role of digitization outdoor is that the path of visual consumption of advertising to the final purchase is a shortcut (through a mobile tool). An ad message will be tied to the place where the consumer is, this phenomenon is called «Location Specific Services» [7].

Contemporary business trading networks dictate the requirements for «Omnia communications», which means not only new models of content distribution, but also creative-driven content when the omnicity is achieved not only by placing advertising information in different channels, but also by complementing social activity with the basis of creative concepts [6].

In contrast to traditionally created advertising messages, new technologies give the possibility to develop such a trend as collaborative 
content of participants of the communication process and sales network. In this case, we may already discuss this phenomenon as consolidation - the combining efforts of individuals, groups, organizations that persecute common goals. This kind of integration allows searching, analysis, creation, and editing, filtering information by both sides - company and content creators. Consumers become international agents in the company: they do not only buy, but also sell in some way when putting ratings on the Internet. Due to the transformation of information environment consumers are able to play different [arts on the business scene. The Internet ratings and feedback which are usually made by consumers are more trusted, nowadays. Each consumer becomes an ambassador of a brand and can shape public opinion concerning myriad topics [6].

Recently, digital games have become widespread as an interactive, personalized and constantly updated communication channel. A shopping mall can stimulate the process of consumption and sales within the game itself, as well as link virtual spaces to the real world. Marketing tools can appear as product placement at the beginning and at the end of the game or placing a logo on the screen throughout the game. Specially-placed codes from products' packages can be used during games as keys for entering next levels. Games can be integrated with the trading company's website or other marketing tools. Network games with a large number of participants allow interacting with each other and directly communicating with the websites implemented in the game brands of goods.

Thus, every year, principles of placing online advertising will increasingly integrate into the offline environment, including more actively used data, the possibility of dynamic, the real-time distribution of advertising. All media will move towards cross-consumption: mobile + outdoor advertising, mobile + radio, mobile $+\mathrm{TV}$, etc. This will increase the personalization of messages and switch to One-to-One communication on a large scale through the use of data [6].

The task of advertisers is to take advantage of digitalization as soon as possible and implement them in the business strategies of enterprises in accordance with the latest trends of the field.

\section{References}

1. Dubrovik-Rokhova A. «Digitalization is just the beginning» [Internet resource] / A. Dubrovik-Rokhov. - Access mode: https://day.kyiv.ua/en/ article/ economics / didzhitalizaciya -eto-lish-nachalo

2. Digital Retailization: Transform or Die [Internet Resource]. - Access mode: https://www.retail.ru/news/145900/ 
3. Michael A. Mobile Marketing. Creating a competitive advantage with the help of wireless technologies: per. from english /AND. Michael, B. Solter; [per. from english O. B. Dutova]. - Moscow: «IDT Group Ltd.», 2007. $-400 \mathrm{p}$.

4. Mobile Blind: How do smartphones make people less impulsive? [Internet resource]. - Access mode: https://lpgenerator.ru/blog/2015/02/ 25/ mobilnaya-slepota-kak-smartfony-delayut-lyudej-menee-impulsivnymi

5. Farkosh O. Catch the moment. Digitalization of business / O. Farkosh [Internet resource]. - Access mode: https://eba.com.ua/article/lovymoment-didzhytalizatsiya-biznesu/

6. How the main media will evolve - television, Internet, outdoor advertising and the press [Internet resource]. - Access mode: https://adindex.ru/specprojects/ marketing-trends-2018/168338.phtml

7. The digitalization of advertising is inevitable [Electronic resource]. Access mode: https://posterscope.com.ua/en/posts/didzhitalizatsiyareklamy-neizbezhna

DOI: http://doi.org/10.31617/k.knute.2019-03-19.02

\title{
PECULIARITIES OF CURRENCY DEPENDENCY - ASPECT OF TRADING AND PRODUCTION
}

\author{
Burkle N. \\ $\mathrm{PhD}$, Associate Professor \\ Schiller International University, Germany
}

Keywords: monetary policy, international trading.

Due to the transition to the policy of floating exchange rate, currently undertaken by many countries of the world, the impact of exchange rates on domestic production becomes particularly important. Growth strategy of manufacturing companies, conducting cross-border financial operations, requires mandatory consideration of the impact of the exchange rate on output. The issue of effective accounting of the exchange rate fluctuations in the strategies of the companies has become particularly acute over the last years. As a result, import substitution has become one of the leading strategic lines of development for the companies. This paper is aimed to present the impact of currency dependency on trading and manufacturing on the examples of Switzerland. The article analyzes theoretical approaches to the assessment of the real exchange rate impact on the manufacturing companies' output. 